\title{
Jolanta Szołno-Koguc
}

Uniwersytet Marii Curie-Skłodowskiej w Lublinie, Wydział Ekonomiczny

e-mail: jszolno@hektor.umcs.lublin.pl

\begin{tabular}{l}
\hline SUBWENCJA OGÓLNA JAKO INSTRUMENT \\
WSPARCIA TRANSFEROWEGO SAMORZĄDU \\
GMINNEGO \\
GENERAL SUBSIDY AS AN INSTRUMENT FOR \\
TRANSFER SUPPORT OF LOCAL GOVERNMENT \\
\hline
\end{tabular}

DOI: $10.15611 /$ pn.2017.485.37

JEL Classification: H71, H72

Streszczenie: Dochody jednostek samorządu terytorialnego obejmują dochody własne oraz transfery z budżetu państwa w postaci subwencji ogólnej oraz dotacji celowych. Transfery stanowią dochód uzupełniający. Stałą formę wparcia, niepowiązaną z określonymi zadaniami realizowanymi przez samorząd, stanowi subwencja ogólna. Celem niniejszego opracowania jest weryfikacja cech i znaczenia subwencji ogólnej dla gmin, z uwzględnieniem aktualnego mechanizmu ustalania wielkości poszczególnych jej komponentów: wyrównawczej, równoważącej i oświatowej. W oparciu o źródła regulacyjne oraz publikowane raporty Ministerstwa Finansów dokonano oceny funkcjonowania instrumentu subwencyjnego w latach 2011-2016. Analiza danych statystycznych potwierdziła kluczową rolę tzw. subwencji oświatowej, przekazywanej każdej jednostce samorządu gminnego, z drugiej zaś strony wskazała na coraz mniejszą liczbę gmin uprawnionych do korzystania z części wyrównawczej i równoważącej.

Słowa kluczowe: finanse samorządowe, transfery z budżetu państwa, subwencja ogólna.

Summary: Income of local government units includes own revenue and transfers from the state budget in the form of general subsidies and targeted subsidies. Transfers are complementary income. A general subsidy unrelated to specific tasks carried out by the local government constitutes permanent support. This study contains an analysis of the essence and relevance, taking into account the current mechanism for determining the size of individual parts of the general subsidy for municipalities. Based on regulatory sources and published reports from the Ministry of Finance, the functioning of the subsidy instrument was reviewed in 20112016. The analysis of statistical data confirmed the key role of the educational component on the other hand, pointing to an ever smaller number of municipalities entitled to use the compensatory part and the balancing one.

Keywords: local government finance, intergovernmental financial transfers, general subsidy. 


\section{Wstęp}

Jednostki samorządu terytorialnego nie dysponują wystarczająco wydajnymi źródłami dochodów własnych. Dla potrzeb adekwatnego finansowania realizowanych przez nie zadań od początku istnienia samorządów terytorialnych w Polsce konieczne jest wsparcie transferowe ich budżetów z budżetu państwa. Środki przekazywane samorządom mają charakter redystrybucyjny, uzupełniają ich dochody własne, dopełniając tym samym określony ustawa zasadniczą katalog dochodów JST ${ }^{1}$. Transfery przekazywane są w formie subwencji ogólnej oraz dotacji celowych.

\section{Przesłanki wsparcia transferowego budżetów samorządowych}

Idea transferów zasilających budżety jednostek samorządowych w polityce finansowej kraju jest związana z zasadami subsydiarności (pomocniczości) i adekwatności, wskazanymi zarówno w Konstytucji RP, jak i w dokumentach traktatowych Unii Europejskiej. Z pierwszej wymienionej reguły wypływa przeświadczenie, iż usługi publiczne powinny być realizowane możliwie najbliżej mieszkańców i jeśli wspólnoty samorządowe na najniższych szczeblach nie są w stanie pokryć związanych z tym wydatków, wówczas wspólnoty wyższego szczebla powinny udzielić im pomocy finansowej [Kancelaria Senatu 2012]. Z kolei zasada adekwatności przewiduje uzyskanie przez JST w wyniku alokacji środków publicznych wystarczających dochodów, dzięki którym będą w stanie pokryć wydatki związane z realizacją powierzonych im zadań [Kornberger-Sokołowska 2013]. Przekazywanie transferów przez państwo jednostkom samorządu terytorialnego w celu uzupełnienia ich budżetów stanowi operacjonalizację wymienionych zasad.

W literaturze przedmiotu poświęca się wiele miejsca zarówno przesłankom, jak i kryteriom stosowania systemu wsparcia transferowego z budżetu państwa do budżetów jednostek samorządu terytorialnego [Piotrowska-Marczak (red.) 2009]. Wśród najczęściej eksponowanych argumentów wymieniane są różnice w potencjale dochodów własnych (przede wszystkim bazie podatkowej) poszczególnych jednostek samorządu terytorialnego, z drugiej zaś konieczność zachowania w skali kraju porównywalnego standardu usług publicznych i społecznych udostępnianych i finansowanych przez władze samorządowe [Guziejewska 2008; Patrzałek 2010, s. 195 i n.; Jastrzębska 2012, s. 116; Swianiewicz 2011, s. 85]. Pojawiają się także argumenty przeciw nadmiernemu stosowaniu instrumentów transferowych, zwłaszcza w kontekście ograniczenia samodzielności finansowej samorządów w wymiarze dochodowym, a w przypadku dotacji celowych także wydatkowym [Kosek-Wojnar 2006; Kopańska 2014].

\footnotetext{
${ }^{1}$ Zgodnie z brzmieniem art. 167 ust. 2 Konstytucji RP: „Dochodami jednostek samorządu terytorialnego są ich dochody własne oraz subwencje ogólne i dotacje celowe z budżetu państwa”.
} 


\section{Istota i funkcje subwencji ogólnej jako najważniejszego z transferów}

Subwencja ogólna, jako transfer przekazywany przez władze państwowe jednostkom samorządu terytorialnego, z jednej strony stanowi wydatek budżetu państwa, z drugiej zaś jest to dochód budżetów samorządowych. Dotyczące jej regulacje prawne zawarte są w: Konstytucji RP, ustawie o dochodach jednostek samorządu terytorialnego, ustawie o finansach publicznych, a także Europejskiej Karcie Samorządu Lokalnego. Żadna ze wskazanych regulacji prawnych nie zawiera określenia terminu „subwencja ogólna”. Natomiast w literaturze przedmiotu najczęściej istota pojęcia definiowana jest poprzez wskazanie cech i funkcji. Subwencja ogólna jako dochód jednostek samorządu terytorialnego cechuje się: ogólnością, bezzwrotnością, nieodpłatnością, stanowi formę dofinansowania każdej jednostki samorządu terytorialnego, budżetowego pochodzenia, ma zobiektywizowany charakter, złożoną strukturę, jej przymiotami są także przymusowość oraz swoboda w wykorzystaniu środków finansowych [Małkiewicz 2013, s. 314]. Ogólność subwencji oznacza, iż przekazywana jest na wykonywanie przez jednostki samorządu ogółu zadań własnych. Jest to cecha, która odróżnia subwencję ogólną od dotacji celowej: w przypadku subwencji nie ma z góry skonkretyzowanego przeznaczenia, natomiast w przypadku dotacji obejmuje środki na wykonanie ściśle określonego zadania. Bezzwrotność subwencji polega na tym, że środki finansowe, które w jej ramach zostały przekazane przez władze państwowe na rzecz JST, nie podlegają zwrotowi, wyjątek stanowią jedynie kwoty nienależnie pobrane. Nieodpłatność oznacza, iż samorządy, otrzymując z budżetu państwa środki publiczne w postaci subwencji, nie mają obowiązku realizacji kontrświadczenia względem Skarbu Państwa. Otrzymując środki finansowe od państwa, nie wykonują wobec niego żadnego wzajemnego zobowiązania.

Środki publiczne, które składają się na kwotę subwencji ogólnej, pochodzą z budżetu państwa. To forma zewnętrznego wsparcia finansowego, gwarantowana jednostkom samorządu terytorialnego konstytucyjnie [Konstytucja RP, art. 167, ust. 2]. Subwencja ogólna wyróżnia się także zobiektywizowanym charakterem, wynikającym z parametrów zawartych w przepisach prawa, określających transparentne kryteria i zasady ustalania kwot dla poszczególnych JST. Ponadto subwencja ogólna stanowi złożoną konstrukcję, każda jej część jest liczona odrębnie, również osobno obliczane są jej wysokości dla każdej kategorii JST.

Przymusowość subwencji oznacza, iż samorządy mają prawo do egzekwowania należnych kwot także w drodze postępowania sądowego, co wynika ze wspomnianej już gwarancji konstytucyjnej. I wreszcie swoboda w wykorzystaniu środków pochodzących z subwencji ogólnej polega na tym, iż jednostki samorządu terytorialnego mogą samodzielnie decydować o przeznaczeniu środków otrzymanych w ramach subwencji ogólnej. Zgodnie z art. 7 ust. 3 ustawy o dochodach jednostek samorządu terytorialnego o przeznaczeniu środków otrzymanych z tytułu subwencji ogólnej decyduje organ stanowiący JST. Cecha ta jest powiązana z ogólnością subwencji, 
to właśnie z ogólności subwencji płynie możliwość swobodnego gospodarowania środkami. Gdyby jednostki samorządowe nie otrzymywały środków finansowych na ogół realizowanych zadań własnych, nie mogłyby swobodnie nimi dysponować.

Nierzadko funkcje subwencji ogólnej eksponowane są w nawiązaniu do klasycznych funkcji finansów publicznych, realizowanych wszak przy wykorzystaniu zróżnicowanych instrumentów i instytucji finansowych. W takim ujęciu obok funkcji fiskalnej (zapewnienia finansowania zadań) oraz wyrównawczej (redystrybucja pionowa i pozioma) [Patrzałek 2015, s. 244] pojawia się funkcja regulacyjna oraz stymulacyjna [Patrzałek 2010, s. 202]. Funkcja regulacyjna polega na przeciwdziałaniu utrwalaniu i pogłębianiu dysproporcji terytorialnego rozkładu źródeł własnych, a co za tym idzie zachowania względnej równomierności także w odniesieniu do realizacji zadań publicznych. Z kolei funkcja stymulacyjna dotyczy wspierania działań samorządów lokalnych i regionalnych na rzecz podnoszenia ich konkurencyjności.

Konstrukcja subwencji ogólnej została uregulowana w ustawie o dochodach jednostek samorządu terytorialnego. Ustawodawca, wprowadzając subwencję ogólną, nie utworzył kilku osobnych kategorii dla każdego typu jednostki samorządu terytorialnego, lecz jedną instytucję prawną dla ogółu jednostek samorządowych w wysokości, która wynika z corocznej ustawy budżetowej. Subwencja ogólna składa się $\mathrm{z}$ trzech części. Dla gmin i powiatów są to: część wyrównawcza, część równoważąca oraz część oświatowa, natomiast dla samorządów wojewódzkich: część wyrównawcza, część regionalna i część oświatowa.

\section{Część wyrównawcza subwencji ogólnej dla gmin}

Zgodnie z ustawą o dochodach jednostek samorządowych część wyrównawcza jest sumą kwoty podstawowej oraz kwoty uzupełniającej. Przyznawana kwota podstawowa uzależniona jest od wysokości wskaźnika dochodów podatkowych, a kwota uzupełniająca zależy od gęstości zaludnienia Wpływy te przekazywane są gminom, które znajdują się w gorszej sytuacji finansowej. Jest to więc pewna forma wsparcia finansowego udzielanego gminom, która ma na celu wyrównanie poziomu dochodów w tych gminach do poziomu przeciętnego wśród gmin.

Do określenia gmin, którym przysługuje kwota podstawowa, służą dwa wskaźniki: $G$ oraz $G g$. Wskaźnik $G$ określa dochody podatkowe ${ }^{2}$ na 1 mieszkańca w gminie i jest to iloraz kwoty dochodów podatkowych gminy z roku poprzedzającego rok bazowy oraz liczby mieszkańców gminy. Wskaźnik $G g$ natomiast to iloraz dochodów podatkowych wszystkich gmin z roku poprzedzającego rok bazowy i liczby mieszkańców kraju. Tabela 1 przedstawia kształtowanie się tego wskaźnika w latach 2011-2016.

${ }^{2}$ Dochody podatkowe są to dochody, które obejmują: podatek od nieruchomości, podatek rolny, podatek leśny, podatek od środków transportowych, podatek od czynności cywilnoprawnych, podatek od osób fizycznych w formie karty podatkowej, udział we wpływach z podatku dochodowego od osób fizycznych, udział we wpływach z podatku dochodowego od osób prawnych oraz wpływy z opłaty skarbowej i eksploatacyjnej. 
Tabela 1. Wielkość wskaźnika dochodów podatkowych dla wszystkich gmin w Polsce w latach 2011-2016 (w zl)

\begin{tabular}{|c|c|c|c|c|c|c|}
\hline Wyszczególnienie & 2011 & 2012 & 2013 & 2014 & 2015 & 2016 \\
\hline Wskaźnik Gg (w zł) & 1180,20 & 1195,67 & 1276,32 & 1358,98 & 1435,18 & 1514,27 \\
\hline
\end{tabular}

Źródło: opracowanie własne na podstawie informacji Ministerstwa Finansów o wskaźnikach dochodów podatkowych gmin na lata 2011-2016 (www.mf.gov.pl).

$\mathrm{Na}$ podstawie zestawienia w tabeli 1 można zauważyć tendencję wzrostową wskaźnika, jego wartość dla 2016 roku wzrosła o 28,31\% w stosunku do roku 2011, natomiast $\mathrm{w}$ porównaniu $\mathrm{z}$ rokiem poprzednim (2015) - o 5,51\%. Obserwowana tendencja w wymiarze statystycznym świadczy o poprawie sytuacji ekonomicznej gmin w Polsce.

Warunkiem uzyskania przez daną gminę subwencji w kwocie podstawowej jest to, aby poziom wskaźnika $G$ nie przekroczył $92 \%$ wielkości wskaźnika $G g$ [Ustawa z 13 listopada 2003, art. 20]. Wysokość należnej kwoty uzależniona jest więc od wskaźnika $G$. Istnieją trzy grupy przynależności wspomnianego wskaźnika do konkretnego przedziału liczbowego i w zależności od tego, w jakim znajduje się gmina, przysługuje jej inny sposób obliczenia i inna kwota środków. Tabela 2 przedstawia sposoby obliczania kwoty podstawowej subwencji dla każdego przedziału.

Tabela 2. Przedziały obliczeniowe kwoty podstawowej subwencji wyrównawczej

\begin{tabular}{|l|c|}
\hline \multicolumn{1}{|c|}{ Przedziały } & Sposób obliczania \\
\hline$G \leq 40 \% G g$ & $K P=l_{m} \times[99 \%(40 \% G g-G)+41,97 \% G g]$ \\
\hline$G \in(40 \% G g, 75 \% G g>$ & $K P=l_{m} \times[83 \%(75 \% G g-G)+12,92 \% G g]$ \\
\hline$G \in(75 \% G g, 92 \% G g)$ & $K P=l_{m} \times[76 \%(92 \% G g-G)]$ \\
\hline
\end{tabular}

Oznaczenia: $G$ - wskaźnik dochodów podatkowych w określonej gminie, $G g$ - wskaźnik przeciętnych dochodów podatkowych gmin, $K P$ - wielkość kwoty podstawowej, $l_{m}$ - liczba mieszkańców określonej gminy.

Źródło: opracowanie własne na podstawie art. 20 ustawy z dnia 13 listopada 2003 r. o dochodach jednostek samorządu terytorialnego (tekst jedn. Dz.U. z 2016, poz. 198 ze zm.).

Tabela 3 zawiera zestawienie liczby gmin ze względu na przynależność do poszczególnych przedziałów obliczeniowych w kwocie podstawowej w latach 20112016.

Analizując wielkości w tabeli 3, można zauważyć, iż blisko 77\% wszystkich gmin w Polsce uprawnionych jest do otrzymywania kwoty podstawowej subwencji. Najbardziej liczną grupę w podziale uwzględniającym poszczególne progi obliczeniowe stanowią gminy ze wskaźnikiem $G$ wynoszącym od $40 \%$ do $75 \%$ przeciętnych dochodów podatkowych. $Z$ roku na rok można zauważyć pozytywną tendencję zmniejszania się liczby gmin, w których dochody podatkowe stanowią mniej 
Tabela 3. Liczba gmin w poszczególnych przedziałach obliczeniowych kwoty podstawowej w latach 2011-2016

\begin{tabular}{|l|r|r|r|r|r|r|}
\hline \multicolumn{1}{|c|}{ Poszczególne przedziały } & 2011 & 2012 & 2013 & 2014 & 2015 & 2016 \\
\hline $\begin{array}{l}G<92 \% G g, \\
\text { w tym: }\end{array}$ & 1970 & 1963 & 1937 & 1889 & 1840 & 1852 \\
\hline $1 . G \leq 40 \% G g$ & 240 & 296 & 231 & 112 & 97 & 88 \\
\hline $2 . G \in(40 \% G g, 75 \% G g>$ & 1321 & 1288 & 1305 & 1268 & 1231 & 1242 \\
\hline 3. $G \in(75 \% G g, 92 \% G g)$ & 409 & 379 & 401 & 509 & 512 & 522 \\
\hline$G \geq 92 \% G g$ & 509 & 516 & 542 & 590 & 639 & 627 \\
\hline Suma & 2479 & 2479 & 2479 & 2479 & 2479 & 2479 \\
\hline
\end{tabular}

Źródło: opracowanie własne na podstawie informacji z Ministerstwa Finansów o wskaźnikach dochodów podatkowych gmin na lata 2011-2016 (www.mf.gov.pl).

niż (bądź są równe) 40\% przeciętnych dochodów podatkowych. Także pojawianie się coraz większej liczby gmin w grupie, której dochody podatkowe przewyższają $92 \%$ wskaźnika $G g$, należy uznać za korzystne zjawisko, coraz większa liczba gmin w Polsce ma wyższe dochody podatkowe.

Poza kwotą podstawową występuje również kwota uzupełniająca, która przyznawana jest gminom, w których poziom gęstości zaludnienia jest niższy od poziomu przeciętnej gęstości zaludnienia w całym kraju. Warunkiem otrzymania tej części jest również posiadanie przez gminę wskaźnika dochodów podatkowych na poziomie mniejszym niż $150 \%$ wskaźnika przeciętnych dochodów podatkowych [Ustawa z 13 listopada 2003, art. 20 ust. 7]. Jeśli gminy spełniają tylko pierwszy z wymienianych warunków, wówczas nie otrzymują one kwoty uzupełniającej, a potencjalne środki trafiają do części równoważącej subwencji. Wielkość kwoty uzupełniającej oblicza się na podstawie poniższego wzoru:

$$
K U=17 \% G g \times l_{m} \times\left[\left(G z-g_{z}\right) / G z\right],
$$

gdzie: $K U$-wielkość kwoty uzupełniającej, $G g$ - wskaźnik przeciętnych dochodów podatkowych gmin, $l_{m}$ - liczba mieszkańców określonej gminy, $G z$ - przeciętna gęstość zaludnienia gmin, $g_{z}$ - gęstość zaludnienia w określonej gminie.

Zgodnie z informacjami ogłoszonymi przez Ministerstwo Finansów w 2016 roku, kwotę uzupełniającą subwencji ogólnej otrzymało 1789 gmin, w tym: 7 miast, 499 gmin wiejsko-miejskich oraz 1333 gminy wiejskie.

\section{Część równoważąca subwencji ogólnej dla gmin}

Część równoważąca jest uzupełnieniem dochodów gmin w nawiązaniu do wprowadzonych od 2004 roku zmian finansowania zadań [Świrska 2011, s. 112]. Jest to transfer wyrównywania poziomego, w którym bogatsze gminy przekazują okre- 
ślone środki finansowe na rzecz gmin o słabej sytuacji finansowej. Wielkość tej części subwencji określają dwa czynniki. Pierwszy to wpłaty gmin, których dochody podatkowe przekraczają poziom $150 \%$ przeciętnych dochodów podatkowych wszystkich gmin w Polsce. Drugim parametrem jest wielkość kwoty uzupełniającej subwencji wyrównawczej nieprzysługującej gminom ze względu na zbyt wysoki dochód podatkowy (większy niż $150 \% \mathrm{Gg}$ ). Jest to zatem nie tylko forma pomocy ze strony państwa, ale również ze strony najbogatszych samorządów. Mechanizm rozdziału subwencji równoważącej na poszczególne gminy w zależności od ich przyporządkowania do jednej z trzech kategorii przedstawia tabela 4. I tak $75 \%$ subwencji w części równoważącej przyznawane jest gminom ze względu na poziom ich określonych wydatków (na dodatki mieszkaniowe), natomiast pozostałe $25 \%$ przekazywane jest na podstawie wysokości określonych dochodów podatkowych (udziału we wpływach z podatku dochodowego od osób fizycznych, podatku rolnego oraz podatku leśnego).

Tabela 4. Podział subwencji równoważącej dla poszczególnych gmin

\begin{tabular}{|l|l|}
\hline $\begin{array}{c}\text { Procentowy } \\
\text { podział subwencji } \\
\text { równoważącej }\end{array}$ & \multicolumn{1}{c|}{ Beneficjenci } \\
\hline $50 \%$ & $\begin{array}{l}\text { Otrzymują gminy miejskie, w których wydatki na dodatki mieszkaniowe na } \\
1 \text { mieszkańca gminy znajdowały się powyżej } 80 \% \text { przeciętnych wydatków } \\
\text { na dodatki mieszkaniowe ogółu gmin miejskich na 1 mieszkańca. }\end{array}$ \\
\hline $25 \%$ & $\begin{array}{l}\text { Otrzymują gminy wiejskie oraz miejsko-wiejskie, w których wydatki na } \\
\text { dodatki mieszkaniowe na jednego mieszkańca znajdowały się powyżej } \\
90 \% \text { przeciętnych wydatków na ten cel na 1 mieszkańca. }\end{array}$ \\
\hline $25 \%$ & $\begin{array}{l}\text { Otrzymują gminy wiejskie oraz miejsko-wiejskie, w których suma } \\
\text { dochodów z tytułu udziału we wpływach z podatku dochodowego od osób } \\
\text { fizycznych i podatku rolnego oraz leśnego na 1 mieszkańca jest mniejsza } \\
\text { niż 80\% przeciętnych dochodów na 1 mieszkańca z powyższych tytułów. }\end{array}$ \\
\hline
\end{tabular}

Źródło: opracowanie własne na podstawie art. 21a Ustawy z dnia 13 listopada 2003 r. o dochodach jednostek samorządu terytorialnego (tekst jedn. Dz.U. z 2015, poz. 513, 789).

Tabela 5 zestawia liczby gmin w Polsce, które uzyskały część równoważącą subwencji w latach 2011-2016. Jak można zauważyć, najwięcej gmin otrzymało subwencję równoważącą w 2012 roku (aż 1622), najmniej uprawnionych gmin odnotowano w 2015 roku (o 183 jednostki w porównaniu z 2012).

Tabela 5. Liczba gmin, które uzyskały subwencję równoważącą w latach 2011-2016

\begin{tabular}{|c|c|c|c|c|c|c|}
\hline Lata & 2011 & 2012 & 2013 & 2014 & 2015 & 2016 \\
\hline Liczba gmin & 1563 & 1622 & 1566 & 1447 & 1439 & 1462 \\
\hline
\end{tabular}

Źródło: opracowanie własne na podstawie danych z Ministerstwa Finansów o ostatecznych kwotach subwencji ogólnej na lata 2011-2016 (www.mf.gov.pl). 
W analizowanych latach pojawia się tendencja spadkowa liczby gmin uprawnionych do jej otrzymania. W 2016 roku część równoważąca subwencji została przekazana 1462 gminom, jest to spadek o prawie 6,5\% w porównaniu z 2011 rokiem. Może to świadczyć o polepszającej się sytuacji ekonomicznej jednostek samorządowych i zmniejszających się dysproporcjach między jednostkami samorządowymi.

\section{Subwencja tzw. oświatowa}

Ostatnią częścią subwencji ogólnej jest subwencja oświatowa. Ten komponent subwencji ogólnej jest najistotniejszym transferem dla samorządu gminnego. Zgodnie z ustawą o dochodach JST wielkość omawianej subwencji jest wyznaczana każdego roku w ustawie budżetowej dla ogółu jednostek samorządu terytorialnego. Wysokość kwoty subwencji oświatowej nie może być niższa niż kwota zawarta w ustawie w roku bazowym. Dodatkowo można ją skorygować o kwotę wydatków związanych ze zmianami w realizowaniu zadań oświatowych. Powyższa kwota jest rozdzielana pomiędzy jednostki samorządowe po uprzednim odliczeniu rezerwy w wysokości $0,4 \%$. Metody podziału subwencji oświatowej wyznaczane są przez ministra właściwego do spraw oświaty i wychowania w drodze rozporządzenia. Wśród kryteriów podziału subwencji oświatowej uwzględniane są: typy i rodzaje szkół oraz placówek prowadzonych przez JST, stopnie awansu zawodowego nauczycieli oraz liczba uczniów szkół i placówek [Ustawa z 13 listopada 2003, art. 27-28]. Są to jedynie przykładowe kryteria, które powinny być brane pod uwagę podczas ustalania części oświatowej. Minister, dokonując podziału subwencji oświatowej, uwzględnić może również inne kryteria, stąd nierzadko wskazuje się, iż ten sposób podziału środków nie jest całkowicie zobiektywizowany [Sawicka, Miemiec, Miemiec 2013, s. 116].

$\mathrm{W}$ tabeli 6 zaprezentowano roczne kwoty subwencji tzw. oświatowej przewidziane dla gmin w latach 2011-2016.

Tabela 6. Kwota subwencji oświatowej dla gmin w latach 2011-2016 (w mld zł)

\begin{tabular}{|l|c|c|c|c|c|c|}
\hline \multicolumn{1}{|c|}{ Wyszczególnienie } & 2011 & 2012 & 2013 & 2014 & 2015 & 2016 \\
\hline $\begin{array}{l}\text { Kwota subwencji } \\
\text { oświatowej dla gmin }\end{array}$ & 21,8 & 23,3 & 23,7 & 24,0 & 25,2 & 26,4 \\
\hline
\end{tabular}

Źródło: opracowanie własne na podstawie danych z Ministerstwa Finansów o ostatecznych kwotach subwencji ogólnej w latach 2011-2016.

W tabeli 6 zauważyć również można tendencję wzrostową wielkości subwencji ogólnej w części oświatowej dla gmin. W ciągu ostatnich kilku lat kwota subwencji wzrosła o ponad $21 \%$, wynika to ze zmiany realizowanych zadań oświatowych przez jednostki samorządowe. Zwiększenie kwoty subwencji oświatowej na 2015 rok było spowodowane uwzględnieniem: skutków finansowych związanych z objęciem obowiązkiem szkolnym dzieci sześcioletnich, środków finansowych w związ- 
ku z pomniejszeniem dochodów własnych z tytułu podatku dochodowego od osób fizycznych (ze względu na planowane zwiększenie ulgi podatkowej na dzieci). Pomimo rosnącego udziału subwencji oświatowej środki otrzymywane na oświatę nie pokrywają wszystkich potrzeb zgłaszanych przez samorządy w tym zakresie. Stąd też wiele dyskusji zarówno w teorii, jak i w praktyce wokół części oświatowej subwencji ogólnej i przekazywanej w ten sposób przez państwo wielkości środków na wsparcie oświaty samorządowej. Chodzi przede wszystkim o adekwatność wymiaru tej części subwencji w stosunku do potrzeb. $Z$ drugiej strony należy zauważyć, iż brak jest podstaw ustawowych, które determinowałyby zobowiązania finansowe budżetu państwa wobec jednostek samorządu terytorialnego (poprzez odniesienie się czy to do zakresu zadań oświatowych, czy też do stawianych systemowi oświaty celów). W obowiązujących regulacjach nie ma bezpośredniego związku pomiędzy częścią oświatową subwencji ogólnej a wydatkami samorządowymi na oświatę [Herbst, Herczyński, Levitas 2009; Czepelak 2015]. Brak celowego charakteru subwencji oświatowej powoduje również, iż w praktyce nie można zarzucić, że kwota otrzymywanej subwencji jest zbyt niska w stosunku do zadań oświatowych finansowanych na terenie danej jednostki samorządu terytorialnego.

\section{Zakończenie}

W polskim systemie finansów samorządowych subwencja ogólna stanowi formę stałego, gwarantowanego konstytucyjnie finansowania JST. Aby spełniała dobrze swoją funkcję dochodową i wyrównawczą, przyznawanie określonych jej kwot powinno następować na podstawie obiektywnych i stabilnych kryteriów, bez bezpośredniego określania celów i zadań, na które te kwoty mają być przeznaczane. Dzięki takiemu mechanizmowi, pomimo jej zewnętrznego charakteru, nienaruszana będzie swoboda w dysponowaniu, a co za tym idzie - utrzymane będą przesłanki samodzielności finansowej JST w wymiarze wydatkowym.

Należy podkreślić, iż utrzymuje się rosnące znaczenie jako źródła finansowania zadań samorządu gminnego tzw. subwencji oświatowej, która przysługuje wszystkim jednostkom, z roku na rok jej kwota rośnie w relacji do zmian w systemie oświaty samorządowej. Spada natomiast liczba gmin uprawnionych do korzystania z części wyrównawczej oraz równoważącej, co z jednej strony może świadczyć o generalnej poprawie sytuacji ekonomicznej polskich gmin, przekładającej się na realizowany poziom dochodów podatkowych, z drugiej zaś wskazywać na zmniejszające się dysproporcje między jednostkami w ramach poszczególnych ich kategorii. 


\section{Literatura}

Czepelak Z., 2015, Standardy edukacyjne realizowane przez samorzady terytorialne, Narodowy Instytut Samorządu Terytorialnego, Ekspertyzy i Opracowania, nr 3 (www.nist.gov.pl).

Europejska Karta Samorządu Terytorialnego, sporządzona w Strasburgu dnia 15 października 1985 r., Dz.U. nr 124, poz. 607.

Guziejewska B., 2008, Zewnętrzne źródła finansowania samorządu terytorialnego, Wydawnictwo Uniwersytetu Łódzkiego, Łódź.

Herbst M., Herczyński J., Levitas A., 2009, Finansowanie oświaty w Polsce - diagnoza, dylematy, możliwości, Wydawnictwo Naukowe Scholar, Warszawa.

Jastrzębska M., 2012, Finanse jednostek samorządu terytorialnego, Wolters Kluwer Polska, Warszawa.

Kancelaria Senatu, 2012, Subsydiarność w prawie i praktyce samorzadowej. Opracowania tematyczne - 609, Warszawa

Konstytucja Rzeczypospolitej Polskiej z dnia 2 kwietnia 1997 r., Dz.U. nr 78, poz. 483 ze zm.

Kopańska A., 2014, Efektywność decentralizacji. Analiza zdecentralizowanego dostarczania dóbr o charakterze ponadlokalnym, Difin, Warszawa.

Kornberger-Sokołowska E., 2013, Zasada adekwatności w systemie finansów samorządu terytorialnego $w$ Polsce, Warszawa.

Kosek-Wojnar M., 2006, Samodzielność finansowa jednostek samorzadu terytorialnego w sferze wydatków, Zeszyty Naukowe Wyższej Szkoły Ekonomicznej w Bochni, nr 4.

Małkiewicz A., 2013, Struktura gminnej subwencji ogólnej, Prawnicza i Ekonomiczna Biblioteka Cyfrowa, Wrocław.

Patrzałek L., 2010, Finanse samorzadu terytorialnego, Wydawnictwo Uniwersytetu Ekonomicznego we Wrocławiu, Wrocław.

Patrzałek L., 2015, Subwencja ogólna, jako instrument korekcyjno-wyrównawczy w systemie finansów samorzadu terytorialnego, Prace Naukowe Uniwersytetu Ekonomicznego we Wrocławiu, nr 404.

Piotrowska-Marczak K. (red.), 2009, Federalizm fiskalny w teorii i praktyce, Difin, Warszawa.

Sawicka K., Miemiec W., Miemiec M., 2013, Prawo finansów publicznych sektora samorzadowego, Wolters Kluwer Polska, Warszawa.

Swianiewicz P., 2011, Finanse samorzadowe. Koncepcje, realizacja, polityki lokalne, Wydawnictwo Municipium SA, Warszawa.

Świrska A., 2011, Ocena subwencjonowania gmin w opinii władz samorząowych, Zeszyty Naukowe Uniwersytetu Przyrodniczo-Humanistycznego w Siedlcach, nr 89.

Ustawa z 13 listopada 2003 r. o dochodach jednostek samorządu terytorialnego, tekst jedn. Dz.U. z 2016, poz. 198 ze zm.

Ustawa z 27 sierpnia 2009 r. o finansach publicznych, tekst jedn. Dz.U. z 2016, poz. 1870 ze zm. 